\title{
Reakcje na sytuacje stresowe w opinii pielęgniarek zatrudnionych w oddziałach zachowawczych
}

\author{
Occupational stress reactions among nurses working \\ in behaviural wards
}

TERESA SIEMIANOWSKA ${ }^{1,2}$, DOMINIKA PODSIADŁY ${ }^{3}$, ROBERT ŚLUSARZ1,4

${ }^{1}$ Instytut Nauk o Zdrowiu PWSZ we Włocławku

${ }^{2}$ Wojewódzki Szpital Specjalistyczny im. Bł. Ks. J. Popiełuszki we Włocławku

3 Oddział Pediatrii, Gastroenterologii, Kardiologii, Neurologii, Diabetologii i Endokrynologii, Regionalny Szpital Specjalistyczny im. Dr. W. Biegańskiego w Grudziądzu

4 Zakład Pielęgniarstwa Neurologicznego i Neurochirurgicznego, CM im. Ludwika Rydygiera w Bydgoszczy

DOI: http://dx.doi.org/10.21784/IwP.2018.019

ISSN: $2451-1846$

\section{Streszczenie:}

Wstęp. Pielęgniarki stanowią grupę zawodową szczególnie narażona na rozwój wypalenia zawodowego.

Cel. Celem przeprowadzonych badań jest analiza strategii radzenia sobie ze stresem wśród pielęgniarek pracujących na oddziałach zachowawczych.

Materiał i metody. Badanie przeprowadzono wśród pielęgniarek i pielęgniarzy pracujących na oddziałach zabiegowych w Regionalnym Szpitalu Specjalistycznym im. dr W. Biegańskiego w Grudziądzu, po uzyskaniu pozytywnej zgody Komisji Bioetycznej Uniwersytetu Mikołaja Kopernika w Toruniu przy Collegium Medicum im. Ludwika Rydygiera w Bydgoszczy oraz zgody Dyrekcji szpitala. Wykorzystano metodę sondażu 
diagnostycznego, technikę ankietowania oraz autorski kwestionariusz ankiety i standaryzowany kwestionariusz Mini-Cope.

Wyniki. Zdecydowanie najczęściej respondenci twierdzili, że praca pielęgniarki/pielęgniarza jest często stresująca. Działania, które służą zmniejszenia stresu to wsparcie ze strony przełożonego i współpracowników oraz poprawa warunków pracy. Strategie radzenia sobie ze stresem jakie wskazywali najczęściej respondenci to: aktywne radzenie sobie, planowanie, zajmowanie się czymś innym, poszukiwanie wsparcia emocjonalnego oraz pozytywne przewartościowanie i rozwój. Stosowane przez pielęgniarki style radzenia sobie ze stresem to aktywne radzenie sobie oraz poszukiwanie wsparcia.

Wnioski. Pielęgniarki z oddziałów zachowawczych w największym stopniu stosowały aktywne radzenie sobie, zarówno jako strategię i styl radzenia sobie ze stresem.

Słowa kluczowe: sytuacje stresowe, pielęgniarki, oddziały zachowawcze

\section{Abstract:}

Introduction. Nurses are particularly vulnerable to proffessional burnout.

Aim. The aim of the study was to analyse different strategies of dealing with occupational stress among nurses working in behavioural wards.

Materials and methods. The study was carried out among nurses working in behavioural wards in dr Biegański Specialist Hospital in Grudziądz. The study was aproved by the Bioethics Committee of Nicolaus Copernicus Univeristy in Torun , Collegium Medicum in Bydgoszcz and the management of the hospital. Standartised Mini-Cope questionnaire torether with a questionnaire prepared by the researchers were used as study tools.

Results. The respondents most often described nursing proffession as stressful. Support from superiors and coworkers and the improvement of working conditions were perceived as stress reducing factors. Active involvment in coping with stress, planning, seek emotional support, personal development and possitive reassesment were the strategies that the respondents used most often. Nurses dealt with stress and saught emotional support as their strategy of coping with stress.

Conclusions. Nurses working in beahavioural wards addopted stress management as their strategy and style of coping with stress.

Keywords: stressful situations, nurses, behavioural ward 


\section{Wstęp}

Stres wpływa na psychikę każdego $\mathrm{z}$ nas a jak na niego reagujemy doświadczamy obserwując własne ciało. Pod jego wpływem w naszym organizmie dochodzi do licznych reakcji. Zasadniczą rolę w fizjologii stresu odgrywają trzy układy: hormonalny, odpornościowy oraz nerwowy. W wyniku zagrożenia $\mathrm{w}$ naszym organizmie dochodzi do pobudzenia części współczulnej autonomicznego układu nerwowego [1]. Wówczas wzrasta stężenia adrenaliny i noradrenaliny we krwi. Dochodzi do przyspieszenia czynności serca, przyspieszenia oddechu, wzrostu rozkurczowego i skurczowego ciśnienia tętniczego krwi oraz podwyższenia poziomu kwasu moczowego we krwi. Ponadto zwiększa się ukrwienie tkanek oraz zaopatrzenie ich $\mathrm{w}$ tlen. Podwyższony poziom epinefryny i norepinefryny podnosi także intelektualną sprawność organizmu. W wyniku stresu rozszerzają się nasze źrenice a w ustach odczuwamy uczucie suchości w wyniku zagęszczenia śliny [2].

Układem, który stanowi ważny element w relacji stres-zdrowie jest system odpornościowy. Jego zadaniem jest chronić organizm przed zaburzeniem równowagi. Należy tutaj wspomnieć o dwóch rodzajach odporności, które są ściśle związane ze stresem: komórkowej i humoralnej. W reakcji odpornościowej typu humoralnego organizm zwalcza infekcje wykorzystując różnego typu substancje chemiczne, $\mathrm{z}$ których najważniejsze to przeciwciała, produkowane przez limfocyty B. Natomiast odporność typu komórkowego jest znacznie dłuższa i jest warunkowana przez limfocyty. W wyniku stresu w układzie odpornościowym dochodzi do osłabienia tego układu w wyniku czego jesteśmy bardziej podatni na choroby. Silne bodźce stresowe powodują także zmniejszenie rozmiaru grasicy [1].

Duże znaczenie $\mathrm{w}$ fizjologii stresu ma też układ hormonalny. Uwalniany $\mathrm{w}$ podwzgórzu hormon kortykotropowy działa synergistycznie stymulując komórki przysadki do uwolnienia hormonu 
adrenokortykotropowego (ACTH). Ten z kolei aktywuje korę nadnerczy do uwolnienia kortykosteroidów: glukokortykoidów oraz mineralkortykoidów które regulują poziom glukozy i elektrolitów we krwi [1]. Głównym glukokortykoidem jest kortyzol. Stanowi on jeden z hormonów, którego wartość zależy od nasilenia stresu ale również od sposobu radzenia sobie $\mathrm{z}$ nim. W wyniku wzrostu poziomu kortyzolu dochodzi do pobudzenia kluczowej struktury dla powstawania emocji - ciałka migdałowatego. Ciało migdałowate ma za zadanie przygotować organizm na niebezpieczeństwo. Tutaj powstają emocje negatywne - strach i gniew [3]. Zwolnione przez oś stresu hormony oraz neurohormony inicjują odpowiedź na poziomie komórek, tkanek i narządów. Wówczas jeśli pobudzana jest część współczulna układu nerwowego możemy obserwować mobilizację organizmu.

Konsekwencje działania stresu możemy zauważyć w trzech wymiarach zdrowia człowieka - w wymiarze psychicznym, społecznym, i fizycznym. Pod względem czasu konsekwencje te dzielimy na natychmiastowe oraz długotrwałe.

Do skutków działania stresu o charakterze natychmiastowym zaliczamy:

- reakcje ze strony układu pokarmowego: biegunka, zaparcia, brak apetytu, niestrawność;

- symptomy oddechowe: przyspieszony płytki oddech, czasami hiperwentylacja;

- bóle głowy, bóle pleców;

- ból żołądka, klatki piersiowej [4].

Skutki długotrwałe stresu to:

- powikłania chorobowe odnoszące się do zdrowia psychicznego,

- powikłania chorobowe dotyczące zdrowia fizycznego [4].

Działania podejmowane są w czasie stresu w celu złagodzenia jego skutków bądź zmiany sytuacji. Podstawę klasyfikacji strategii radzenia sobie ze stresem stanowią dwa czynniki: modalność radzenia 
sobie oraz funkcjonalność czyli zwrócenie strategii na rozwiązanie problemu [5]. Radzenie sobie z sytuacją stresową stanowi dynamiczny proces, w którym o podjętej strategii decydują m.in. indywidualne właściwości, bowiem każdy $\mathrm{z}$ nas przejawia inny mechanizm reagowania na stresowe sytuacje [6]. Styl radzenia sobie ze stresem to zbiór strategii charakterystyczny dla danej jednostki z kolei strategią nazywamy sposób w jaki sobie radzimy z przeciwnościami [4].

Zjawiskiem występowania wypalenia zawodowego wśród pielęgniarek interesowali się już naukowcy od wielu lat. Pielęgniarki stanowią grupę zawodową, która predysponuje do wypalenia zawodowego. W badaniach Pasikowskiego wyróżniono kategorie uciążliwości spostrzeżeń pielęgniarki. Zalicza się do nich: wymagania wypływające ze specyfiki pracy, małe zarobki, niski status społeczny, zła współpraca z pacjentem i jego rodziną [7]. Problem wypalenia jest większy jeśli proces zaczyna się skrycie, i ma charakter chroniczny [8].

Celem przeprowadzonych badań jest analiza strategii radzenia sobie ze stresem wśród pielęgniarek pracujących na oddziałach zachowawczych.

\section{Materiał i metody}

Badanie przeprowadzono wśród pielęgniarek i pielęgniarzy pracujących na oddziałach zabiegowych w Regionalnym Szpitalu Specjalistycznym im. dr W. Biegańskiego w Grudziądzu. Na wykonanie badań uzyskano zgodę Komisji Bioetycznej Uniwersytetu Mikołaja Kopernika w Toruniu przy Collegium Medicum im. Ludwika Rydygiera w Bydgoszczy oraz zgodę Dyrekcji szpitala.

Wykorzystano metodę sondażu diagnostycznego, technikę ankietowania oraz autorski kwestionariusz ankiety i standaryzowany kwestionariusz Mini-Cope. 
Do wykonania obliczeń wykorzystany został pakiet statystyczny Statistica 10.0 i arkusz kalkulacyjny Microsoft Excel wykorzystując standardowe funkcje tego programu.

\section{Wyniki}

Tabela 1. Średnie wieku badanych.

\begin{tabular}{|c|c|c|c|c|c|c|c|c|c|c|}
\hline Oddział & $\mathbf{N}$ & $\begin{array}{l}\text { Średn } \\
\text { ia }\end{array}$ & SD & $\begin{array}{l}\text { Ufno } \\
\text { ść } \\
- \\
95,0 \\
\%\end{array}$ & $\begin{array}{l}\text { Ufnoś } \\
\text { ć } \\
+95,0 \\
\%\end{array}$ & $\begin{array}{l}\text { minim } \\
\text { um }\end{array}$ & $\begin{array}{l}\text { maksim } \\
\text { um }\end{array}$ & $\begin{array}{l}\text { Q2 } \\
5\end{array}$ & $\begin{array}{l}\text { media } \\
\text { na }\end{array}$ & $\begin{array}{l}\text { Q7 } \\
5\end{array}$ \\
\hline $\begin{array}{l}\text { Zachowaw } \\
\text { czy }\end{array}$ & $\begin{array}{l}3 \\
2\end{array}$ & 46,3 & $\begin{array}{l}7,37 \\
7\end{array}$ & $\begin{array}{l}43,6 \\
8\end{array}$ & 49,00 & 29,0 & 58,0 & $\begin{array}{l}42, \\
5\end{array}$ & 47,0 & $\begin{array}{l}50, \\
0\end{array}$ \\
\hline
\end{tabular}

Źródło: wynik badań własnych

Średnia wieku badanych wyniosła nieco ponad 46 lat. Najmłodsza badana osoba miała 29 lat a najstarsza 58 lat.

Tabela 2. Wykształcenie badanych.

\begin{tabular}{|l|l|l|}
\hline wykształcenie & N & $\%$ \\
\hline liceum medyczne & 18 & 56,3 \\
\hline studium medyczne & 2 & 6,3 \\
\hline licencjat pielęgniarstwa & 9 & 28,1 \\
\hline magister pielęgniarstwa & 3 & 9,4 \\
\hline razem & 32 & 100,0 \\
\hline
\end{tabular}

Źródło: wynik badań własnych 
Znaczna większość badanych ukończyła liceum medyczne - 18 osób (56,3\%), a tylko 3 osoby $(9,4 \%)$ uzyskały tytuł magistra pielęgniarstwa oraz ukończyły studium medyczne - 2 osoby $(6,3 \%)$.

Tabela 3. Stresujący charakter pracy pielęgniarki/ pielęgniarza $w$ opinii badanych.

\begin{tabular}{|l|l|l|}
\hline odpowiedź & N & $\%$ \\
\hline często & 25 & 78,1 \\
\hline czasami & 7 & 21,9 \\
\hline nigdy & 0 & 0,0 \\
\hline razem & 32 & 100,0 \\
\hline
\end{tabular}

Źródło: wynik badań własnych

Najwięcej badanych odpowiedziało, że praca pielęgniarki/pielęgniarza jest często stresująca 25 osób (78,1\%). Nikt z badanych nie wskazał że jego praca nigdy go nie stresuje.

Tabela 4. Działania jakie należy podjąć w celu zmniejszenia stresu w pracy w opinii badanych.

\begin{tabular}{|c|c|c|}
\hline działania & $\mathrm{N}$ & $\%$ \\
\hline wsparcie ze strony przełożonego & $\begin{array}{l}2 \\
3\end{array}$ & 23,5 \\
\hline wsparcie ze strony współpracowników & $\begin{array}{l}2 \\
3\end{array}$ & 23,5 \\
\hline opieka psychologiczna & $\begin{array}{l}1 \\
3\end{array}$ & 13,3 \\
\hline poprawa warunków pracy & $\begin{array}{l}2 \\
1\end{array}$ & 21,4 \\
\hline
\end{tabular}




\begin{tabular}{|l|l|l|}
\hline działania edukacyjne z zakresu wypalenia zawodowego oraz stresu w & 1 & 18,4 \\
miejscu pracy & 8 & \\
\hline razem & 9 & 100 \\
& 8 & 0 \\
\hline
\end{tabular}

Źródło: wynik badań własnych

Respondenci odpowiadając na pytanie o działania jakie należałoby podjąć $\mathrm{w}$ celu zmniejszenia stresu $\mathrm{w}$ pracy, zaznaczali po kilka stwierdzeń. najwięcej badanych uznało, że w celu zmniejszenia stresu niezbędne jest wsparcie ze strony przełożonego i wsparcie ze strony współpracowników - po 23 osoby (po 23,5\%) oraz poprawę warunków pracy - 21 osób (21,4\%). Najmniej zakreśliło opiekę psychologiczną - 13 osób (13,3\%).

Tabela 5. Średnie wyniki strategii radzenia sobie ze stresem.

\begin{tabular}{|l|l|l|}
\hline strategia & średnia & SD \\
\hline aktywne radzenie sobie & 2,00 & 0,65 \\
\hline planowanie & 1,92 & 0,56 \\
\hline pozytywne przewartościowanie & 1,66 & 0,63 \\
\hline akceptacja & 1,56 & 0,72 \\
\hline poczucie humoru & 0,64 & 0,53 \\
\hline zwrot ku religii & 0,98 & 1,00 \\
\hline poszukiwanie wsparcia emocjonalnego & 1,83 & 0,77 \\
\hline poszukiwanie wsparcia instrumentalnego & 1,52 & 0,77 \\
\hline zajmowanie się czymś innym & 1,83 & 0,59 \\
\hline
\end{tabular}




\begin{tabular}{|l|l|l|}
\hline zaprzeczanie & 0,66 & 0,60 \\
\hline wyładowanie & 1,17 & 0,67 \\
\hline zażywanie substancji psychoaktywnych & 0,23 & 0,40 \\
\hline zaprzestanie działań & 0,55 & 0,59 \\
\hline obwinianie siebie & 1,16 & 0,68 \\
\hline
\end{tabular}

Źródło: wynik badań własnych

Respondenci w największym stopniu stosowali takie strategie radzenia sobie ze stresem jak: aktywne radzenie sobie - 2,0 punkty, planowanie - 1,92 punktu, zajmowanie się czymś innym - 1,83 punktu, poszukiwanie wsparcia emocjonalnego - 1,83 punktu oraz pozytywne przewartościowanie i rozwój - 1,66 punktu. W najmniejszym stopniu: zaprzeczanie - 0,66 punktu, poczucie humoru - 0,64 punktu, zaprzestanie działań - 0,55 punktu, oraz zażywanie substancji psychoaktywnych $-0,23$ punktu.

Tabela 6. Średnie stylów radzenia sobie ze stresem.

\begin{tabular}{|l|l|l|}
\hline styl (czynnik) & średnia & SD \\
\hline aktywne radzenie sobie & 1,86 & 0,46 \\
\hline bezradność & 0,65 & 0,40 \\
\hline poszukiwanie wsparcia & 1,67 & 0,71 \\
\hline zachowania unikowe & 1,22 & 0,41 \\
\hline zwrot ku religii & 0,98 & 1,00 \\
\hline akceptacja & 1,56 & 0,72 \\
\hline
\end{tabular}




\begin{tabular}{|l|l|l|}
\hline poczucie humoru & 0,64 & 0,53 \\
\hline
\end{tabular}

Źródło: wynik badań własnych

Respondenci stosowali najczęściej takie style radzenie sobie ze stresem jak: aktywne radzenie sobie - 1,86 punktu oraz poszukiwanie wsparcia - 1,67 punktu. W najmniejszym stopniu respondenci wybierali takie strategie jak: bezradność - 0,65 punktu oraz poczucie humoru - 0,64 punktu.

\section{Dyskusja}

Współczesne pielęgniarstwo zyskuje coraz większe znaczenie w systemie opieki zdrowotnej; stanowi jej nieodłączny element. Profesjonalizacja zawodu pielęgniarki prowadzi do zwiększenia stopnia odpowiedzialności za drugą osobę, ale wymaga także coraz to wyższego poziomu kwalifikacji. W pracy pielęgniarki podmiotem pracy jest człowiek, dlatego tak ważne są interpersonalne relacje. To właśnie od pielęgniarki wymaga się umiejętności nawiązywania kontaktów, dobrej współpracy z pacjentami i pozostałym personelem a także niezawodnej komunikacji. Pacjenci darzą pielęgniarki dużym zaufaniem. Praca pielęgniarki cechuje się dużą odpowiedzialnością za życie drugiego człowieka, dlatego też tak często utożsamiana jest $\mathrm{z}$ dużym stresem [8].

Niemożność spełnienia wszystkich oczekiwań przez pielęgniarkę, szczególnie w polskich warunkach, gdzie obsady personelu są dalekie od standardów panujących w krajach zachodnich, często prowadzi do odczuwania przez nią poczucia bezsilności, a często i winy, co jest nierzadko przyczyną wzrostu napięcia w kontaktach z samym pacjentem i jego rodziną, a niejednokrotnie również z personelem lekarskim [9]. Przeciwdziałanie zjawisku stresu zawodowego nie jest zadaniem prostym, dlatego należy połączyć wysiłki pracodawcy, związków zawodowych, służb BHP oraz lekarzy 
medycyny pracy i innych ekspertów by zapewnić wszystkim pracownikom, w tym również pielęgniarkom, bezpieczne, higieniczne i możliwie wolne od stresu warunki pracy [10].

Celem aktualnej pracy była analiza strategii i sposobów radzenia sobie ze stresem $\mathrm{w}$ grupie pielęgniarek pracujących na oddziałach zachowawczych.

Wszyscy ankietowani w badaniach własnych uznali pracę pielęgniarki za stresującą, a blisko $80 \%$ uznało, że stres w pracy jest częsty. Nikt z respondentów nie wskazał, że stres nigdy się nie pojawia.

Doniesienia z literatury również wskazują na znaczący odsetek ankietowanych pielęgniarek przekonanych o stresogenności swojego zawodu. W badaniach Kowalczuk i wsp. [20] prawie trzy czwarte ankietowanych pielęgniarek było narażonych na stres. Zbliżony wynik uzyskano w badaniach Modzelewskiej i Kulik [11]. Wykazano bowiem, że blisko trzy czwarte ankietowanych pielęgniarek $\mathrm{z}$ Lublina odczuwało stres związany z wykonywaną pracą. Pietraszek i wsp. [12] badali 278 pielęgniarek z Lublina i Krosna. Ponad 95\% respondentek stwierdziło, że ich zawód jest stresujący, a ponad połowa deklarowała, że sytuacje stresujące mają miejsce w ich pracy zawodowej codziennie. W pracy Wzorek [13] przedstawiono wyniki europejskich badań NEXT, które dotyczyły analizy zjawiska stresu w pracy pielęgniarek w 10 europejskich krajach. Tylko pielęgniarki niemieckie były bardziej narażone na stres od polskich.

Analiza wyników podaje, że działania jakie należałoby podjąć $\mathrm{w}$ celu zmniejszenia stresu w pracy $\mathrm{w}$ większości dotyczą wsparcia ze strony przełożonego i wsparcia ze strony współpracowników. Literatura potwierdza także wyniki dotyczące działań, które należałoby podjąć w celu zmniejszenia stresu w pracy. Utrzymująca się od wielu lat frustracja oraz niezadowolenie $\mathrm{z}$ pracy zawodowej $\mathrm{w}$ środowisku polskich pielęgniarek może budzić uzasadniony niepokój. Proces ten wpływa negatywnie na rozwój profesji i może w przyszłości być źródłem poważnego kryzysu. 
W aktualnych badaniach znacząca większość badanych deklarowała, że próbuje radzić sobie ze stresem w pracy zawodowej. Najczęściej stosowanymi strategiami radzenia sobie ze stresem były aktywne radzenie sobie, planowanie, zajmowanie się czymś innym, poszukiwanie wsparcia emocjonalnego oraz pozytywne przewartościowanie i rozwój. Najmniej popularne strategie to z kolei: zaprzeczanie, poczucie humoru, zaprzestanie działań, oraz zażywanie substancji psychoaktywnych.

Badane pielęgniarki stosowały najczęściej następujące style radzenia sobie ze stresem: aktywne radzenie sobie oraz poszukiwanie wsparcia. W najmniejszym stopniu wybierali style: bezradność oraz poczucie humoru.

Żuralska i wsp. [14] przedstawili w swej pracy trzy strategie radzenia sobie ze stresem: styl skoncentrowany na zadaniu (podejmowanie wysiłku poznawczego), styl skoncentrowany na emocjach (koncentrowanie się na własnych reakcjach emocjonalnych) i styl skoncentrowany na unikaniu (niemyślenie o problemie). Autorzy podkreślają, że osoba posiadająca więcej różnorodnych strategii radzenia sobie ze stresem, może je bardziej elastycznie i skutecznie wykorzystywać. Rola stylu skoncentrowanego na zadaniu została podkreślona $\mathrm{w}$ rozumieniu dobrostanu, który sprzyja rozwojowi subiektywnego stanu zdrowia.

W badaniach Nyklewicza i Krajewskiej-Kułak [15], które objęły 100 studentów pielęgniarstwa $\mathrm{z}$ Białegostoku, zarejestrowano zadaniową reakcję na stres u $22 \%$ z nich. Styl skoncentrowany na emocjach odnotowano u $9 \%$ pielęgniarek, zaś styl skoncentrowany na unikaniu - również u $9 \%$ badanych. Wśród pozostałych $60 \%$ pielęgniarek żaden z tych stylów nie był dominujący. Również badania Żuralskiej i wsp. [14] wykazały dominującą rolę stylu skoncentrowanego na zadaniu i poszukiwaniu kontaktów towarzyskich $w$ trudnej sytuacji, niż stylu skoncentrowanego na unikaniu i emocjach. W badaniach autorów zaobserwowano również, że pielęgniarki o krótszym stażu pracy częściej stosowały styl 
skoncentrowany na zadaniu w porównaniu do badanych o dłuższym stażu pracy.

\section{Wnioski}

1. Zawód pielęgniarki/pielęgniarza ma często charakter stresujący.

2. Działaniami, który należ podjąć w celu zmniejszenia stresu jest wsparcie ze strony przełożonego i wsparcie ze strony współpracowników oraz poprawa warunków pracy.

3. Strategiami radzenia sobie ze stresem jest aktywne radzenie sobie, planowanie, zajmowanie się czymś innym, poszukiwanie wsparcia emocjonalnego oraz pozytywne przewartościowanie i rozwój.

4. Stosowanymi stylami radzenia sobie ze stresem są aktywne radzenie sobie oraz poszukiwanie wsparcia.

\section{Zalecenia dla praktyki pielęgniarskiej}

Przeciwdziałając zjawisku stresu wśród pielęgniarek i pielęgniarzy należy zwiększyć nacisk na relacje międzyludzkie w zespole terapeutycznym, a zwłaszcza wzmocnienie wsparcia ze strony przełożonych i współpracowników. Ważnym elementem zmniejszenia stresu będzie także poprawa warunków pracy.

Działania te mogą znacząco zredukować poziom stresu, a w konsekwencji zwiększyć poczucie satysfakcji zawodowej oraz wpłynąć na poziom i jakość świadczeń realizowanych przez pielęgniarki i pielęgniarzy. 


\section{Bibliografia/Bibliography:}

1. Wrona-Polańska H.: Zdrowie, stres, choroba w wymiarze psychologicznym. Wyd. Impuls, Kraków 2008; 21-25.

2. Borys B., Majkowicz M.: Psychologia w medycynie. Wyd. AMG, Gdańsk 2006;67-108,160-196.

3. Walden- Gałuszko K.: Psychoonkologia w praktyce klinicznej. Wyd. LekarskiePZWL, Warszawa 2014; 179-185.

4. Waszkowska M., Potocka A., Wojtaszczyk P.: Miejsce pracy na miarę oczekiwań - poradnik dla pracowników socjalnych. Wyd. Instytut Medycyny Pracy, Łódź 2010; 9-43.

5. Basińska M.A., Kasprzak A.: Związek między strategiami radzenia sobie ze stresem a akceptacją choroby w grupie osób chorych na łuszczycę. Przegląd Dermatologiczny 2012;6: 692-700.

6. Sygit- Kowalkowska E.: Radzenie sobie ze stresem jako zachowanie zdrowotne człowieka- perspektywa psychologiczna. Hygeia Public Health 2014; 49(2): 202-208.

7. Cepuch G., Dębska G.: Wypalenie zawodowe u pielęgniarek pracujących w zakładach opieki zdrowotnej. Problemy Pielęgniarstwa 2008;16;3 : 273-279.

8. Wilczek-Rużyczka E.: Wypalenie zawodowe a empatia u lekarzy i pielęgniarek. Wyd. Uniwersytetu Jagiellońskiego 2008; 46-49.

9. Kędra E, Nowocień M.: Czynniki stresogenne a ryzyko wypalenia zawodowego w pracy pielęgniarek. Pielęgniarstwo Polskie 2015; 3(57): 293-306.

10. Stres w miejscu pracy- stan prawny, przeciwdziałanie oraz działania związków zawodowych. 
http://www.opzz.org.pl/documents/707532/707723/publikacja+s tres.pdf [dostęp: 08.06.2017].

11. Modzelewska T, Kulik T.B.: Stres zawodowy jako nieodłączny element zawodów profesjonalnego pomagania - sposoby radzenia sobie ze stresem w opinii pielęgniarek. AnnalesUniversitatis Maria Skłodowska-Curie, Lublin - Polonia, 2000; LVIII, supl. VIII, 161 sectio D: 312-316.

12. Pietraszek A, Charzyńska-Gula M, Łuczyk M, Szadowska-Szlachetka Z, Kachaniuk H, Kwiatkowska J.: Analiza przyczyn stresu zawodowego w opinii pielęgniarek. Journal of Education, Health and Sport. 2016; 6 (9): 643-652.

13. Wzorek A.: Porównanie przyczyn stresu wśród pielęgniarek pracujących na oddziałach o różnej specyfice. Studia Medyczne 2008; 11:33-37.

14. Żuralska R, Mziray M, Postrożny D, Domagała P.: Poczucie własnej skuteczności a style radzenia sobie z sytuacją trudną u pielęgniarek pracujących z chorym umierającym. Przedsiębiorczość i Zarządzanie 2014; XV (12,Część II): 131-141.

15. Skorupska-Król A, Szabla A, Bodys-Cupak I.: Opinie pielęgniarek na temat czynników stresogennych związanych $\mathrm{z}$ ich środowiskiem pracy. Pielęgniarstwo XXI wieku 2014; 1(46): 23-26. 